\title{
Relevansi Pelembagaan Investasi Ekonomi Berbasis Shariah Pada Masyarakat Muslim di Mindanao
}

\section{Surwandono}

Magister Hubungan Internasional, Universitas Muhammadiyah Yogyakarta

Ringroad Barat Tamantirto, Kasihan, Bantul 55183

Email: wsurwandono@yahoo.com

Diterima pada 12 Desember 2014, Disetujui pada 17 Februari 2015

\begin{abstract}
The idea of building shariah economic investment institution was pioneered by Muhammadiyah when involved in the International Contact Group (ICG) to strengthening civil capacity of the muslim mindanao community through the transformation of social, economy, and education, as the initation of Baitul Mal Wa Tamwil establishment, as the embryo of economic shariah investment institution. This article will build a new idea which in the community who experiencing conflict still need shariah economic investment institution. Institute of shariah economic will guide the choice toward politic and military confrontation to more moderate and measureable in the community, which is in the end will contributes positively in creating peace.

Key Words: Economic investment, Shariah economic institution, Muslim community which in conflict.
\end{abstract}

\begin{abstract}
Abstrak
Gagasan tentang membangun pelembagaan investasi ekonomi shariah dipelopori oleh Muhammadiyah, ketika Muhammadiyah tergabung dalam International Contact Group (ICG) untuk melakukan sejumlah penguatan kapasitas sipil masyarakat Muslim Mindanao melalui transformasi sosial, ekonomi, dan pendidikan, seperti inisiasi pembuatan Baitul Mal Wa Tamwil, sebagai embrio pelembagaan investasi ekonomi shariah. Tulisan ini akan membangun gagasan baru bahwa dalam masyarakat yang sedang mengalami konflik pun tetap membutuhkan ikhtiar pelembagaan investasi ekonomi shariah. Pelembagaan ekonomi shariah akan memandu pilihan konfrontasi politik dan militer menjadi lebih moderat dan terukur dalam masyarakat yang sedang mengalami konflik, yang pada akhirnya akan memberikan kontribusi positif bagi terciptanya perdamaian.

Kata Kunci: Investasi Ekonomi, Pelembagaan Ekonomi Shariah, Masyarakat Muslim Yang Berkonflik
\end{abstract}

\section{PENDAHULUAN}

Konflik Mindanao merupakan konflik yang sangat tua dan klasik, yang melibatkan penduduk Mindanao dengan penduduk di luar Mindanao. Dinamika konflik Mindanao berawal dari perlawanan penduduk Mindanao terhadap upaya kolonialisasi oleh Spanyol yang telah berhasil menguasai kepulauan Luzon dan hendak meluaskan wilayah pengaruhnya ke bagian selatan Luzon di abad 15 M.Pada periode berikutnya, konflik Mindanao kembali menunjukkan momentum yang dinamis ketika transisi regim kolonial Spanyol ke regim Amerika Serikat menjelang perang dunia ke II. Dan kemudian bertransformasi lagi, ketika Amerika Serikat memberikan kemerdekaan atas Filipina dan menempatkan kepulauan Mindanao sebagai wilayah politik dan administrasi Filipina.

Pasca kemerdekaan Filipina, 4 Juli 1946, konflik Mindanao terjadi antara pemerintah Filipina dengan masyarakat Mindanao. Kebijakan pemerintah Filipina Manuel Quezon yang hendak menghapuskan struktur budaya, hukum dan politik dan diganti dengan 
Tabel 1

Intensitas Konflik di Mindanao

\begin{tabular}{lllll} 
Location & Incompatibility & Opposition Organization & Years & Intensity Level \\
\hline Philippines & Territorial & Mindanao Independent & $1970-1971$ & Minor \\
& Movement (MIM) & $1972-1977$ & Minor \\
& Territorial & MNLF (Moro National & $1978 *$ & Wars \\
& Liberation Front), & $1979-1980$ & Minor \\
& MLLF (Moro Islamic & $1982-1990$ & Wars \\
& Liberation Front) & $1993-1996$ & Minor \\
& MNLF, MILF, Amerika & $1996-1999^{*}$ & War \\
& SerikatG (Abu Sayyaf & 2000-2003* & Intermediete \\
& Groups) & \\
\hline \multirow{2}{*}{ Sumber: Journal of Peace Research, vol. 42, no. 5, Sage Publications (London, Thousand Oaks, CA and New Delhi)2005, pp. 623-635 }
\end{tabular}

struktur hokum,budaya dan politik yang berbasis hokum positif di Filipina. Pilihan kebijakan Manuel Quezon ini mendapatkan perlawanan keras dari para datus di Mindanao karena difahami akan mengancam legitimasi para datus maupun mengancam identitas Islam yang sudah berakar di Mindanao semenjak abad ke 15. (Cesar Adib Mahul, 1973)

Periode paling krusial konflik antara pemerintah Filipina dengan masyarakat Mindanao adalah pada masa presiden Marcos antara tahun 1968-1972.Dalam periode ini, respon pemerintah Filipina terhadap keinginan masyaraat Mindanao untuk melakukan pemisahan diri, cenderung menggunakan pendekatan represif.Beragam penyiksaan, pembunuhan, ataupun mengirim pasukan sipil, dalam hal ini etnis Ilaga untuk membantai masyarakat Mindanao cenderung menjadi kebijakan pokok dengan diberlakuannya Martial Law. (Cesar Adib Mahul, 1973)

Konflik antara pemerintah Filipina dengan masyarakat Mindanao kemudian menjadi konflik bersenjata (armed conflict). Dalam konflik bersenjata ini telah menyebabkan lebih dari 120.000 orang terbunuh, 55.000 orang terluka, menghabiskan anggaran militer Filipina sampai $40 \%$ per tahun senilai lebih dari 73 milyar Peso, 30\% budget Angkatan Udara, 40\% budget Angkatan Laut, dan 60\% budget Angkatan Darat dialokasikan ke Mindanao.(Carolina Hernandez, 2002)

Internasionalisasi konflik di Mindanao oleh MNLF menghasilkan respon serius dari masyarakat internasional, khususnya dari Dunia Islam.
Serangkaian perjanjian kemudian dilakukan antara pemerintah Filipina dengan perwakilan Mindanao yang diwakili oleh MNLF dengan mediator dari OKI dan negara-negara muslim seperti Libya, Indonesia, Malaysia, Arab Saudi, Jordania. Perjanjian yang pertama antara pemerintah Filipina dengan Kelompok Perlawanan Moro adalah Tripoli Agreement 1976 yang dilaksanakan di Libya. Pada era Corazon Aquinno yang melahirkan Jeddah Accord, 3 Januari 1987, yang menghasilkan pemerintah otonomi Moro (Autonomous Region for Moro). ARMM berhak mengelola wilayah otonomi secara penuh kepada lima propinsi besar yakni Sulu, Basilan, Tawi-Tawi, Maguindano, Palawan, maka jalan perdamaian kembali terbuka. Pada era pemerintahan Fidel Ramos, Final Peace Agreement berhasil disepakati oleh kedua belah fihak yang berkonflik, dengan ditandatanganinya dokumen hasil negosiasi oleh Nur Misuari yang mewakili MNLF dan Fidel Ramos yang mewakili pemerintah Filipina. Proses penandatangan Final Peace Agreement 1996, dengan disaksikan oleh menteri luar negeri Indonesia Ali Alatas dan Sekretaris Jendral Organisasi Konferensi Islam, Hamid Algabid (Surwandono,2013)

\section{HASIL DAN PEMBAHASAN}

DAMPAK KONFLIK MINDANAO

Merujuk studi yang dipublikasikan oleh Journal of Peace Research (2005), konflik Mindanao dapat terkategorikan ke dalam 3 kategori besar, dari konflik minor di mana konflik terjadi dengan intensitas rendah dengan area yang terbatas, dengan penggunaan 
instrument kekerasan minimal, konflik intermediate, di mana intensitas dan wilayah konflik cenderung meningkat dan meluas, disertai dengan penggunaan intrumen kekerasan, maupun dalam level War, di mana konflik sudah terjadi dalam bentuk konfrontasi fisik dengan menggunakan intrumen kekerasan dan senjata api. Konflik dalam level War terjadi dalam beberapa tahun saja, namun sebagian besar level konfliknya adalah intermediate.Yang agak unik adalah justru konflik dalam level war justru terjadi pada kurun waktu pasca tercapainya kesepakatan damai (Surwandono, 2013)

Terkait dengan kedalaman konflik di Mindanao, studi yang dilakukan oleh International Cross Red Crescent (2009) melakukan survey terhadap stakeholder konflik Mindanao.Hal yang paling dikhawatirkan dari stakeholder konflik di Mindanao adalah terusir dari tempat tinggalnya dengan segala hal yang melekat di dalamnya yang mencapai angka 52\% dan tidak mendapatkan akses kebutuhan dasar seperti air, listrik (19\%) dan tinggal di wilayah di mana dikendalikan oleh fihak musuh (18\%), serta kehilangan lapangan pekerjaan (14\%).

\section{Tabel 2}

Angka Human Development Index (HDI) di Propinsi Mindanao

\begin{tabular}{ll} 
Province & HDI \\
Sulu & 0.31 \\
Maguindanao & 0.36 \\
Tawi-Tawi & 0.36 \\
Basilan & 0.41 \\
Masbate & 0.44 \\
Zamboaga del Norte & 0.45 \\
Sarangani & 0.45 \\
Western Samar & 0.47 \\
Eastern Samar & 0.47 \\
Lanao del Sur & 0.48 \\
\hline
\end{tabular}

Sumber: Human Development Index Philippines, 2005

Terdapat sejumlah studi yang mencoba melihat relasi antara tetap tinggi konflik di Mindanao dengan derajat ekonomi di tingkat makro maupun mikro di Mindanao. Studi Persatuan Bangsa-Bangsa (PBB) yang melakukan pengukuran terhadap Human Develop- ment Index (HDI) di Mindanao menunjukan bahwa tingginya intensitas konflik di Mindanao berpengaruh sangat kuat terhadap derajat perekonomian. Terdapat kecenderungan daerah-daerah di Mindanao yang menjadi episentrum konflik Mindanao indeks HDI jauh berada di bawah rata-rata nasional di Filipina. Indeks HDI Filipina pada angka 6,5, dan propinsi yang tidak mengalami konflik semisal di Cebu angka HDI mencapai angka 7,2 (Surwandono, 2013)

Studi Amina Rasul,(2007) menunjukkan efek ganda dari masih berlangsung konflik di Mindanao adalah merosotnya kapasitas ekonomi suatu wilayah yang mengalami konflik secara masif. Sebagai ilustrasi dalam studi penulis di Filipina, wilayah konflik di Mindanao Gross Regional Productnya jauh dari angka rata-rata nasional, bahkan hanya $1 / 4$ dari rata-rata nasional, dan jika dikaitkan dengan Gross Regional Product di Manila, posisi Gross Regional Product di Mindanao hanya 1/10 GrossDomestic Product seperti yang tercermin dalam tabel berikut:

\section{Tabel 3}

Gross Regional Product Daerah Yang Mengalami Konflik Masif

\begin{tabular}{llllll} 
Region & 2001 & 2002 & 2003 & 2005 & 2006 \\
\hline National & 12.746 & 12.843 & 13.798 & 14.186 & 14.647 \\
Metro Manila & 30.048 & 30.077 & 33.667 & 35.742 & 37.855 \\
Cordillera & 17.74 & 17.889 & 18.111 & 17.919 & 18.171 \\
Bicol & 5.95 & 6.060 & 6.442 & 6.632 & 6.685 \\
Muslim & 3.799 & 4.455 & 3.382 & 3.433 & 3.480 \\
$\begin{array}{l}\text { Mindanao } \\
\text { Caraga }\end{array}$ & 6.820 & 4.900 & 6.589 & 6.690 & 6.912 \\
\hline Sumber: Amina Rasul, "Contending Viewpoints Viewpoints: Analyzing The 1996 MNLF-GRP Final \\
\multicolumn{5}{c}{ Peace Agreement", Manila, 2007 }
\end{tabular}

Studi Amina Rasul (2007) juga menunjukkan bahwa terdapat kecenderungan peningkatan kemiskinan dalam kurun waktu 1997 sampai dengan tahun 2003.Periode ini merujuk studi dari Journal of Peace Research, merupakan periode di mana derajat konflik dalam level war, meskipun sebenarnya periode ini terjadi pasca perjanjian damai 1996, antara pemerintah Filipina dengan MNLF. Perubahan pemerintahan di Filipina dari Fidel Ramos yang cenderung melakukan kebijakan all-out peace, ke Erick 
Tabel 4

Angka Pendapatan Perkapita di Propinsi ARMM

per Tahun 1997-2003

\begin{tabular}{lllll} 
Propinsi & 1997 & 2000 & 2003 & $\begin{array}{l}\% \text { change } \\
\text { from 1997- } \\
2003\end{array}$ \\
\hline Maguindanao & 21.915 .00 & 19.967 .00 & 14.198 .00 & $-35 \%$ \\
Basilan & 22.260 .00 & 13.193 .00 & 13.265 .00 & $-40 \%$ \\
Tawi Tawi & 19.794 .00 & 11.340 .00 & 10.780 .00 & $-45 \%$ \\
Sulu & 8.994 .00 & 7.850 .00 & 8.430 .00 & $-6,2 \%$ \\
\hline
\end{tabular}

Sumber: Amina Rasul, "Contending Viewpoints Viewpoints: Analyzing The 1996 MNLF-GRP Final Peace Agreement", Manila, 2007

Estrada yang cenderung melakukan kebijakan all-out war terhadap kelompok bersenjata di Mindanao.

Riset yang Philippine Human Development Report tahun 2003 melaporkan bahwa angka harapan hidup di wilayah ARMM seperti propinsi Basilan, Lanao del Sur, Sulu, Maguindanao, dan Tawi-Tawi merupakan daerah dengan angka harapan hidup terendah di Filipina. Dalam konteks pelembagaan Final Peace Agreement 1996dalam meningkatkan kesejahteraan ARMM.

\section{Tabel 5}

Indeks Harapan Hidup Propinsi di Filipina Tahun 2003

\begin{tabular}{|c|c|c|c|}
\hline Top ten Provinces & Years & Bottom Ten Provinces & Years \\
\hline Cebu & 72.6 & Antique & 62.6 \\
\hline Pampanga & 72.2 & Kalingga & 62.5 \\
\hline 3atangas & 71.8 & Apayao & 62.4 \\
\hline Bulacan & 71.4 & Estearn Samar & 61.7 \\
\hline Camarines Sur & 71.3 & Western Samar & 61.4 \\
\hline Nueva Ecija & 71.2 & Basilan* & 60.6 \\
\hline Davao del Sur & 71.1 & Lanao Del Sur* & 57.9 \\
\hline Rizal & 71 & Sulu* & 52.8 \\
\hline Union & 70.6 & Maguindanao* & 52 \\
\hline ivite & 70.5 & Tawi Tawi * & 51.2 \\
\hline
\end{tabular}

Ket: yang bertanda bintang adalah propinsi yang berada di Mindanao Sumber: Philippines Human Development Report, 2005

\section{MUHAMMADIYAH DAN PERDAMAIAN MINDANAO}

Muhammadiyah adalah salah satu organisasi Islam terbesar di Indonesia, yang telah berdiri semenjak tahun 1911 oleh KH. Ahmad Dahlan.

Muhammadiyah merupakan organisasi sosial keagamaan yang mengkombinasikan tradisi pemurniaan (puritanism) ajaran Islam sekaligus mengembangkan tradisi pembaharuan (tajdid) Islam. (Munir Mulkhan, 2006) Implikasi dari kedua kombinasi gerakan pemikiran tersebut, Muhammadiyah tumbuh menjadi organisasi yang modernis dalam pemikiran maupun dinamis dalam pengembangan amal usaha di bidang pendidikan, kesehatan, pemberdayaan ekonomi, kebudayaan, dan sekarang ini telah mengembangkan diri sebagai organisasi internasional dengan dibukanya Pimpinan Cabang Istimewa Muhammadiyah (PCIM) di beberapa negara seperti Malaysia, Jepang, Taiwan, Mesir, Turki.

Perkembangan Muhammadiyah yang semakin mengglobal, menuntut Muhammadiyah untuk merespon dan melibatkan diri dalam sejumlah persoalan internasional, baik yang menyangkut persoalan dunia Islam maupun kemanusiaan pada umumnya. Keterlibatan Muhammadiyah dalam menyemaikan semangat perdamaian dunia, teraktualisasi dalam Global Peace Forum, forum yang mendiskursuskan pemikiran keagamaan dan perdamaian. Ketua Umum Muhammadiyah, Prof. Din Syamsudin menjadi presiden dari GPF sejak tahun 2009 sampai sekarang. 
Pemikiran dan aksi Muhammadiyah dalam mendiskursuskan perdamaian menarik perhatian sejumlah kalangan, baik dari unsur pemerintah maupun non pemerintah, yang selama ini aktif dalam menjalankan peran humaniter dan perdamaian. Pemerintah Thailand dan Filipina, secara khusus meminta Muhammadiyah untuk terlibat dalam proses pembangunan perdamaian di Thailand Selatan, maupun di Mindanao. Bahkan kelompok Patani, baik yang berafiliasi dengan PULO (Pattani Union of Liberation Organization) ataupun BRN (Barisan Revolusioner Nasional) sebagai fihak yang berkonflik dengan pemerintah Thailand juga menerima usulan pemerintah Thailand terhadap keterlibatan Muhammadiyah. Demikian pula yang terjadi di Mindanao, kelompok MILF (Moro Islamic Liberation Front) juga menyetujui Muhammadiyah menjadi salah satu anggota dari International Contact Group (ICG), bersama dengan organisasi The Asian Foundation, Centre for Humanitarian Dialogoue, Conciliation Resources, untuk menfasilitasi perdamaian di Mindanao. (Humanitarian Dialogue, 2013)

Muhammadiyah kemudian menunjuk 3 orang yakni Prof.Dr, Din Syamsudin, Dr. Sudibyo Markus dan Dr. Surwandono untuk menjadi representative Muhammadiyah dalam ICG. Muhammadiyah menjadi organisasi yang unik dibandingkan dengan anggota ICG yang lain, di mana Muhammadiyah banyak menjalankan peran penting untuk perpersuasi kedua belah fihak yang berkonflik dengan menggunakan narasi bahasa keagamaan, dan solusi praktis keagamaan. Untuk keperluan tersebut Muhammadiyah melakukan pengiriman dua misi untuk melakukan sejumlah assesment terhadap situasi dan kondisi sosial, ekonomi dan keagamaan di Mindanao. Pertama, mengirimkan dua duta Muhammadiyah, yakni Dr. Sudibyo Markus dan Dr. Surwandono untuk melakukan komunikasi di tingkat elit MILF dengan sejumlah tim panel perdamaian yang mewakili Mindanao. Sekaligus juga melakukan komunikasi dengan panel perdamaian dari pemerintah Filipina, dan kedutaan besar republik Indonesia di Filipina untuk membahas cara yang terbaik dalam penyusunan program perdamaian di Mindanao (http:// www.muhammadiyah.or.id)

Kedua, mengirimkan tim assesment, yang terdiri dari Dr. Sudibyo Markus, Dr. Surwandono, Prof. Dr. Imam Robandi, Ahmad Ma'ruf,SE,M,Si, dan Tri Hastuti S.Sos,M.Si, untuk melakukan assesment di tingkat grass-root pada sejumlah lembaga pendidikan, lembaga ekonomi, lembaga sosial, lembaga amal, yang berafiliasi dengan MILF. Tim kemudian menyusun sebuah program 5 tahunan untuk mengubah pola organisasi MILF dari organisasi yang berbasiskan organisasi perlawanan bersenjata menjadi organisasi sosial keagamaan yang berbasiskan organisasi sosial, pendidikan, ekonomi sehingga perdamaian di Mindanao akan lebih mudah terwujud. Program ini kemudian dikomunikasikan dengan sejumlah fihak yang terkait untuk mendapatkan masukan dan dukungan dari berbagai fihak.

Salah satu ide besar yang ditawarkan Muhammadiyah adalah pengembangan masyarakat damai di Mindanao adalah pelembagaan micro finance berbasiskan shariah islam atau yang sering dikenal di Indonesia dengan istilah Baitul Maal Wa Tamwil (BMT). Gagasan sederhana ini muncul tatkala melakukan sejumlahassesment dengan kalangan perempuan Mindanao tentang manajemen pengelolaan ekonomi keluarga, di mana para keluarga di Mindanao memiliki kebiasaan untuk menyisihkan uang di tengah sejumlah keterbatasan sosial ekonomi yang mereka alami. Kebiasaan menabung ini sangat kebutuhan yang strategis bagi eksistensi masyarakat Islam Mndanao pada umumnya, karena dengan menabung ini maka masyarakat Muslim Mindanao merasa berkontribusi bagi kelangsungan perjuangan masyarakat islam Mindanao secara keseluruhan.

Lantas apa yang kemudian disebut investasi paling penting bagi Muslim Mindanao? Demikian pertanyaan besar yang dihadapi para assesor Muhammadiyah. Melalui sebuah focused group discussion, investasi yang paling penting adalah menjaga kesinambungan peran serta seluruh Muslim Mindanao untuk membiayai konflik untuk memperjuangkan kepentingan muslim Mindanao secara keseluruhan. Menabnun melalui 
upaya menyisihan sejumlah potensi keuangan untuk membiayai kehidupan para combatant yang tinggal di hutan, bergerilya untuk mempertahankan harga diri masyarakat muslim Mindanao. Untuk satu keluarga, rata-rata menyisihkan antara 10 Peso untuk setiap minggunya, sehingga secara asumsi sederhana setiap keluarga akan berkontribusi sekitar 50 Peso untuk setiap bulannya, dan sekitar 600 Peso untuk setiap tahunnya.

Dari sinilah kemudian Muhammadiyah melakukan sejumlah curah gagas dengan para elit MILF tentang pengembangan ekonomi mikro lewat sebuah ide pendirian Baitul Maal Wa Tamwil. Pada awal curah gagas, gagasan pendirian BMT sebagai media membangun investasi di tengah situasi konfliktual adalah sesuatu yang absurd, dan tidak masuk akal. Dalam masyarakat yang sedang berkonflik investasi yang paling strategis adalah bagaimana memobilisasi potensi sosial, ekonomi dan politik masyarakat untuk menjadi kekuatan yang besar untuk mengalahkan fihak lain. Potensi ekonomi justru dimobilisasi untuk kepentingan politik konflik.

Dr. Sudibyo Markus memiliki pandangan yang unik tentang makna investasi di tengah konflik, dengan mengambil sebuah narasi yang pernah disampaikan oleh Nabi Muhammad SAW, tentang tamsil menanam pohon di saat terjadi peperangan.

"Seorang muslim tidak menanam tanaman kecuali apa yang dimakan dari tanaman itu menjadi sedekah baginya.Apa yang dicuri dari tanaman itu menjadi sedekah baginya. Apa yang dimakan binatang buas menjadi sedekah baginya. Apa yang dimakan burung menjadi sedekah baginya. Dan tidaklah orang lain mengambil manfaat (dari pohon iti) kecuali menjadi sedekah bagi (penanam)nya. "(HR Muslim dari Ibnu Numair).

Hadits ini memiliki makna, bahwa investasi dalam Islam tidaklah hanya sekedar memberikan keuntungan secara langsung kepada para investor, namun sesungguhnya dibalik investasi tersebut terdapat sedekah, baik langsung maupun tidak langsung. Sehingga makna dari narasi ini adalah tidak ada ruang yang kosong bagi siapa saja untuk melakukan kebaikan. Demikian juga hadist yang bernarasikan tentang arti pentingnya menanam, berinvestasi dalam segala kondisi kehidupan, yang menyatakan bahwa:

"Jika hari kiamat telah tegak, sedang di tangan seorang diantara kalian terdapat bibit pohon, maka tanamlah". (Hr Muslim)

Hadis tentang makna menanam pohon, oleh sejumlah ahli hadist memiliki makna denotatif atau makna dasar, maupun makna kiasan atau metafora. Secara denotatif, investasi tersebut terkait dengan fenomena investasi di bidang pertanian. Investasi di bidang pertanian merupakan investasi yang paling menguntungkan. Namun dalam makna kiasan, investasi tidak hanya di bidang pertanian semata, namun di semua bidang ekonomi yang memungkinkan terjadi perputaran arus uang, jasa dan modal.

Bagi Muhammadiyah, investasi ekonomi di saat situasi konfliktual bukanlah menjadi halangan bagi Muslim Mindanao untuk mencoba menerapkan prinsip ekonomi shariah. Prinsip ekonomi shariah yang berlandaskan kepada konsepsi keadilan bagi investor maupun pengelola memungkinkan proses pembangunan ekonomi di saat krisispun akan tetap bisa berjalan. Sejumlah studi tentang ekonomi konvensional, cenderung melihat fenomena krisis sosial adalah situasi yang paling menakutkan dalam bidang investasi, karena dengan asumsi investasi tidak berjalan, atau bahkan akan mengalami penurunan nilai investasi yang sangat tajam. Sejumlah bukti menunjukkan bahwa lembaga ekonomi shariah di banyak negara, tatkala pasar regional dan global mengalami pelemahan dan krsis ekonomi, pangsa ekonomi shariah tetap mampu berjalan dan menopang lalu lintas perdagangan dan investasi ekonomi.

\section{PELEMBAGAAN SOSIAL EKONOMI ISLAM DI MINDANAO \\ Mindanao merupakan kawasan yang memiliki keanekaragaman sumber daya ekonomi yang tinggi, dari sumber daya di bidang pertanian, perkebunan, sampai dengan sumber daya alam di bidang pertambangan.Studi Solimon Santosmenunjukan}


Tabel 6

Rencana Pembangunan Ekonomi dan Sosial Muhammadiyah di Mindanao

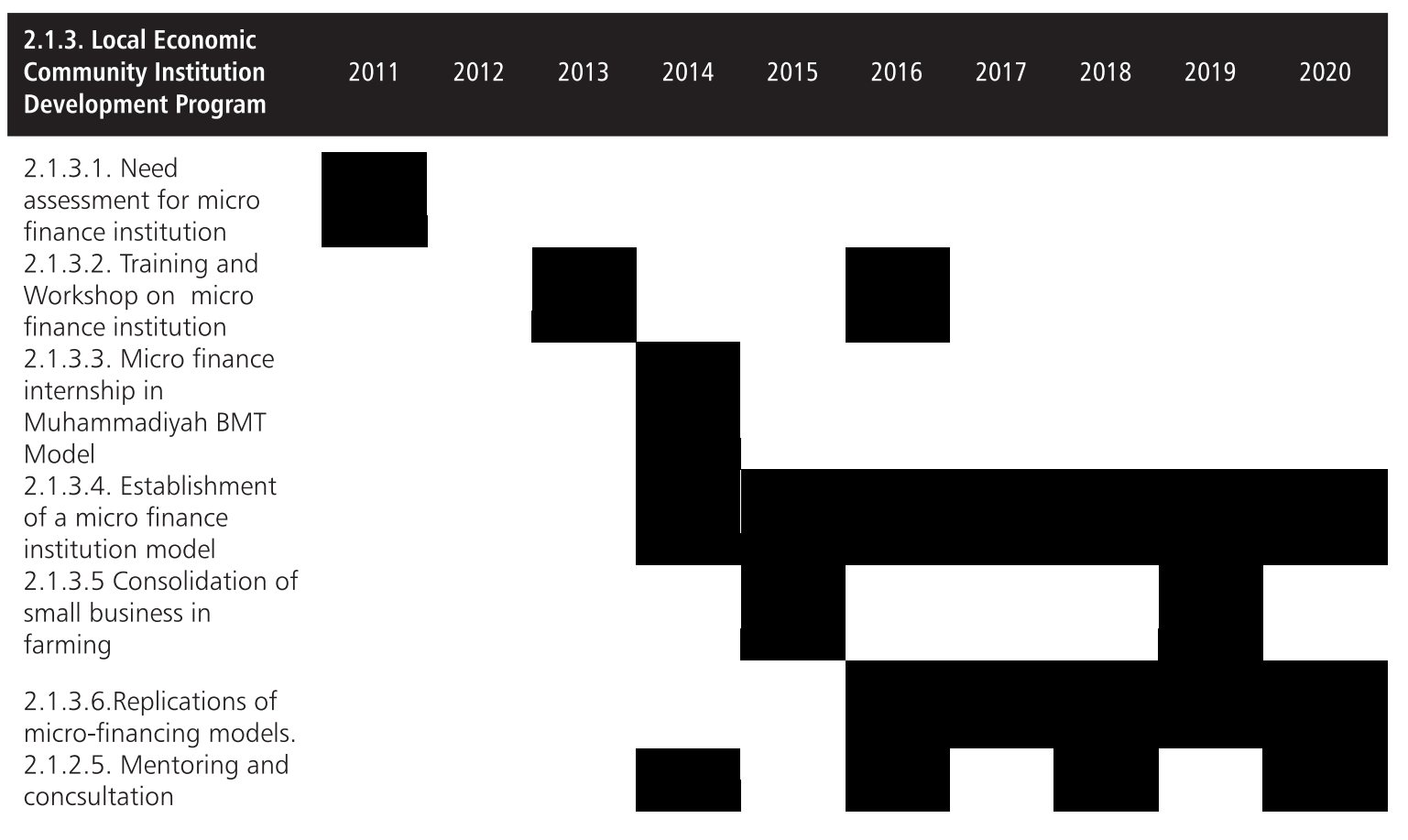

Sumber: Dokumen Muhammadiyah untuk Mindanao, 2011

\section{Tabel 7}

Kontribusi Mindanao Terhadap Pendapatan Nasional Filipina 1990

\begin{tabular}{ll} 
Jenis Sumberdaya & Kontribusi \\
\hline $\begin{array}{l}\text { Suplai beras } \\
\text { Suplai Cattle and }\end{array}$ & $25 \%$ \\
$\begin{array}{l}\text { Tuna } \\
\text { Suplai jagung, } \\
\text { ayam, ikan }\end{array}$ & $57 \%$ \\
$\begin{array}{l}\text { Suplai buah } \\
\text { buahan }\end{array}$ & $100 \%$ \\
$\begin{array}{l}\text { Suplai Plywood, } \\
\text { venner }\end{array}$ & $90 \%$ \\
$\begin{array}{l}\text { Nikel } \\
\text { Emas }\end{array}$ & $63.00 \%$ \\
$\begin{array}{l}\text { Sumber daya } \\
\text { hutan }\end{array}$ & $48.30 \%$ \\
Pertanian & $35 \%$ \\
\hline
\end{tabular}

Sumber: Solimon Santos, The Philippines-Muslim Dispute: Internastional Aspects from Origins to Resolution, Quezon City, 1999 gambaran kongkrit bahwa kepulauan Mindanao memiliki potensi alam yang besar dalam bidang agraris dan ekstraktif.Sedemikian besar potensi ekonomi Mindanao menyebabkan pemerintah Filipina dari era Ferdinand Marcos, sampai Ninoy Aquino berusaha dengan sangat serius untuk mempertahankan otoritas Filipina atas Mindanao (Solimon Santos, 1999)

Merujuk studi Solimon Santos, kepulauan Mindanao juga memiliki lahan hutan seluas 5,41 juta hektar yang potensial sebagai penghasil kayu. Produksi kayu bulat Mindanao berjumlah 72\% dari total produk nasional pada tahun yang sama. Sebagian besar aktivitas bisnis ekstraksi kayu terkonsentrasi di Mindanao.Selain itu, Laut Mindanao, Sulu dan Palawan memiliki kelimpahan sumber daya yang luar biasa.Hampir 59\% tangkapan ikan negara tersebut berasal dari perairan Mindanao.Laut Sulu merupakan produsen terbesar dengan nilai sebesar 34\% dari total produksi nasional.Daerah tangkapan terbesar lainnya adalah Teluk Moro dan Selat Basilan (Solimon Santos, 2003) 
Gambaran data di atas mencerminkan bahwa Mindanao merupakan wilayah yang memiliki potensi yang luas di bidang pertanian, peternakan, perikanan, maupun pertambangan. Namun jika dibandingkan dengan data pada tabel 2 sampai dengan tabel 5 dengan tabel 7, maka sesungguhnya masyarakat Mindanao memiliki potensi yang besar untuk menjadi wilayah pertumbuhan baru di Filipina. Selama ini, pertumbuhan ekonomi di Mindanao memang penurunan yang sangat signifikan, terkait dengan tingginya level konflik di Mindanao, sehingga investasi di Mindanao cenderung tidak mengalami perkembangan.

Untuk memacu pertumbuhan ekonomi di Mindanao, pemerintah Filipina di era Fidel Ramos merumuskan kebijakan Mini-Marshall Plan sebagai salah satu kesepakatan damai di tahun 1996, yang diharapkan dapat memacu pertumbuhan ekonomi dengan mendistribusikan sumber daya ekonomi. Namun, program mini-Marshall Plan untuk Mindanao tidak banyak berjalan dengan baik, terkait dengan perubahan kebijakan pemerintah Estrada yang mengembangkan kebijakan all-out war terhadap kelompok perlawanan Moro.

Pelembagaan ekonomi Islam, sejatinya sudah diinisiasi oleh pemerintah Ferdinand Marcos di tahun 1973, sebagai bagian dari diplomasi pemerintah Marcos terhadap tekanan dunia Islam terhadap Filipina, melalui pendirian Bank Amana.Namun, Bank Amana tidak banyak berkontribusi besar bagi pertumbuhan di Mindanao karena justru Bank ini berpusat di Manila dan dimiliki kepemilikannya oleh pemerintah Filipina.

Pada waktu negosiasi perjanjian pada Final Peace Agreement 1996, issue tentang pelembagan Bank Islam juga menjadi salah satu issue kritikal yang diperjuangkan agar Mindanao memiliki otoritas pengelolaan ekonomi shariah. Namun, Mahkamah Agung Filipina, membatalkan tentang tentang promisi bagi implementasi ekonomi shariah di Mindanao secara luas. Sehingga, peran dari Bank Amana juga tidak mendapatkan otoritas yang luas untuk berkembang di Mindanao.Dalam kurun waktu 15 tahun terakhir, pertumbuhan Bank Amana tidaklah berkembang dengan pesat, sebagaimana yang terjadi di sejumlah Negara dengan penduduk mayoritas Islam di Asia Tenggara, seperti di Indonesia, maupun Malaysia. Bank Amana hanya memiliki 9 kantor cabang, dan 8 di antara berada di wilayah Mindanao.

Tidak berkembangnya Bank Islam di Filipina, merujuk studi dari Atty. Arifa A. Ala, Director, BSP, terkait erat dengan regulasi kebijakan yang kurang ramah terhadap beroperasinya Bank Islam dan infrastruktur yang kurang menunjang bagi beroperasi bank Islam.Ada 4 problem besar:

Pertama, Persoalan yang terkait dengan regulasi kebijakan pemerintah yang tidak kondusif bagi berkembang Bank berbasis Shariah, sehingga bank yang berbasis shariah tidak kompetitif dibandingkan dengan bank konvensional. .....Laws are not able to anticipate the need for a system engaging many Islamic banking players, R.A. No. 6848 is limited to Al-Amanah Bank,Tax laws/ regulations create taxdisparities (Islamic finance products are subject to more taxes; become more costly), Existing laws do not provide for necessary infrastructures such as lender of last resort, deposit insurance system and secondary markets.

Kedua, masih langka dan kurangnya ahli perbankan shariah di Filipina, baik di level pembauat regulasi kebijakan ataupun pelaksana perbankan Islam......Lack or scarcity of experts on Islamic banking/finance - regulators and industry alike.

Ketiga, masih rendahnya kesadaran, penerimaan dan minat dari investor untuk berinvestasi di perbankan yang berbasis shariah....Lack or very low investor awareness and acceptance of Islamic banking/ finance.

Keempat, masih belum jelasnya informasi tentang perbankan shariah maupun produk-produk di dalamnya kepada publik Filipina. Merujuk data Atty. Arifa A. Ala, Director, BSP, jumlah kantor bank yang beroperasi di Mindanao kurang dari 1000 bank, dengan ketersediaan ATM sekitar 1200, dan hanya ada 8 kantor cabang dari bank Amana.Berbeda jauh dengan ketersediaan kantor cabang Bank di kepulauan Luzon yang mencapai angka 6000 lebih dengan jumlah ketersdiaan ATM lebih dari 12.000. Sebagian besar 
Bank berada di wilayah kota-kota penting saja, dan tidak menyebar di sebagian besar wilayah Mindanao.

Mensikapi kondisi perbankan dan investasi yang sangat minimal di Mindanao, pemerintah Filipina pada era Benigno Aquinno Junior setelah melakukan perjanjian damai dengan MILF di tahun 2012, mulai merilis kebijakan yang mencoba mempercepat pertumbuhan ekonomi dan investasi di Mindanao dengan sejumlah cara:

Pertama, menyediakan system yang kompetetif dan memberikan ruang bagi public untuk memilih produk investasi dari sejumlah system perbankan yang ada, baik yang berbasis shariah ataupun non shariah. .... the system must allow for a critical mass of market players under a competitive but well regulated environment. .

Kedua, membuat system jaringan yang memadai, yang mampu untuk mengakomodasi keunikan perbankan Islam. .... appropriate linkages, including inter-bank markets that cater to the unique characteristics of Islamic banking, must be present.

Ketiga, membuat kerangka regulasi dan pengawasan yang memungkinkan perbankan Islam dalam berjalan secara efektif sebagaimana perbankan konvensional. .... the regulatory and supervisory framework must encourage a level playing field where the Islamic banking system can operate alongside conventional banking.

Keempat, membuat iklim kebijakan yang dapat memperkuat inovasi jasa, layanan, produk dari perbankan shariah ... the regulatory environment must encourage the provision of innovative products and services to address the distinctive needs of Islamic finance.

Kelima, membuat kerangka kebijakan yang mampu membantu membangun konsumen yang lebih luas, dengan meningkatkan kesadaran dan penerimaan investor melalui pembuatan jaminan proteksi bagi konsumen. .....the regulatory framework must help build a broader customer and asset base by increasing investor awareness and acceptance, while ensuring consumer protection. (http://www.bsp.gov.ph/ publications/speeches.asp?id=456 akses 20 Januari 2015)
Pada sisi yang lain, pelembagaan Islam yang berbasis micro-finace yang bersifat bottom up belum banyak ditempuh dan dioperasionalkan. Ide Muhammadiyah melalui pendirian BMT sebagai embrio ekonomi Shariah belum banyak direspon secara memadai oleh stakeholder ekonomi muslim Mindanao. Bagi muslim Mindanao, ide dan artikulasi lembaga ekonomi mikro seperti halnya BMT sebagai lembaga investasi ekonomi merupakan hal yang sangat baru. Sebagian besar elit politik MILF yang menjadi mitra Muhammadiyah dalam pembangunan perdamaian hanya mengetahui konsep BMT dalam khasanah fiqh dan normative, dan agak sulit membayangkan di tingkat realita social. Kondisi ini sangat dimaklumi, karena bagi masyarakat Mindanao konsepsi ekonomi Islam selama ini memang identik dengan bank Islam Amana. Bank Islam Amana merupakan satu-satunya Bank di Filipina yang menerapkan prinsip Shariah dengan tidak memberikan bunga atas sebuah penyimpangan maupun peminjaman. Bank ini hanya memiliki kantor di wilayah Mindanao dalam jumlah yang sangat terbatas dan berkantor pusat di Manila.

Tawaran Muhammadiyah untuk mengerakan roda ekonomi Mindanao melalui pola investasi keuangan mikro, sesungguhnya sangat sederhana dan visible. Mata pencaharian masyarakat muslim Mindanao yang berbasis pertanian, peternakan, dan perikanan, memungkinkan BMT jauh lebih mobil, dinamis, dibandingkan dengan model ekonomi finansial berbasis non shariah, yang lebih berorientasi profit seeking semata. Untuk keperluan tersebut, Muhammadiyah mendesaian suatu road pelembagaan ekonomi micro berbasis shariah sebagaimana yang terpapar dalam tabel 6 .

Berseiring dengan semakin terlembaganya perdamaian di Mindanao, Mindanao Development Authority (MinDA), memprediksi pertubuhan ekonomi Mindanao akan mencapai 7\%-8\%, sebuah angka pertumbuhan yang sangat tinggi. Untuk mendukung rencana ini, pemerintah Filipina akan mengalokasikan 30\% dana infrastruktur nasional diperuntukan untuk pembangunan di Mindanao. (http://www.mb.com.ph/7-8-gdp-growth-in- 
mindanao-for-2015-seen/ diakses pada 20 Januari 2015)

\section{INVESTASI EKONOMI SHARIAH DAN KETIDAKPASTIAN SOSIAL DAN PERDAMAIAN}

Sejumlah studi tentang investasi dengan ketidakpastian investasi dalam studi ekonomi Islam merujuk kepada dua tesis besar.(Qudeer Latif, Susia Crawford, 2010, Kamal Abdelkarim Hassan, Hassan Ahmed Yusuf, 2010, Mehmet Asutay, 2010, Sami Ibrahim Al-Suwailem,2002) Pertama, pandangan ulama cenderung melihat investasi dengan unsur ketidakpastian didekatkan dengan fenomena money gaming, ataupun dekat dengan unsur perjudian. Istilah yang sering dikenal dalam agama adalah gharar.Para ulama menghukumi investasi dalam masalah seperti ini dengan hukum haram, atau dilarang untuk dilakukan karena menginvestasikan sesuatu dengan tidak mampu mengelola ketidakpastian itu sendiri.Kedua, Pandangan ulama yang memandang bahwa investasi yang dilakukan di tengah ketidakpastian namun mampu untuk diukur dan dikelola oleh fihak-fihak yang berinvestasi secara produktif, maka para ulama memberikan dalil diijinkannya aktivitas investasi ini.

Dalam masyarakat yang memiliki indeks konflik yang tinggi, dari level intermediate sampai war, ada asumsi besar bahwa ketidakpastian terhadap pertumbuhan investasi akan sangat tinggi. Sehingga pada umumnya investor yang berada di luar wilayah yang berkonflik cenderung untuk tidak bersedia menanamkan investasinya di daerah yang sedang berkonflik.Investor cenderung tidak mampu mengelola sejumlah perilaku konflik, dan cenderung hanya menjadi korban (victims) atau obyek dalam konflik social tersebut.Dalam konteks inilah kemudian kebijakan pemerintah yang berbasis kebijakan kestabilan politik menjadi intrumen penting untuk mengundang para investor dari luar wilayah tersebut (Angelo M. Venardos, 2005, Ibrahim Warde, 2000)

Akan tetapi sangat berbeda, jika yang berinvestasi adalah penduduk local bahkan yang terlibat dalam sejumlah konflik yang ada dalam masyarakat.Investor dan sekaligus sebagai pelaku konflik, hakaketnya memiliki kuasa untuk menggerakan arah konflik untuk mengamankan investasinya ataupun untuk tidak mengamankan investasinya. Dalam konteks ini, ketidakpastian sistuasi sosial dan ekonomi, sesungguhnya hanya sebagai variabel tergantung, sedangkan perilaku konflik dari para stakeholder konflik sesungguhnya sebagai variabel bebasnnya. Artinya, konfik yang demikian ini merupakan ketidakpastian yang dapat diukur dan dikelola oleh masyarakat.

Sepanjang pengamatan tim Muhammadiyah ketika melakukan sejumlah asessment terhadap pusat pendidikan, sekolah, universitas, lahan pertanian, perkebunan, kebanyakan dikelola dan dimiliki oleh para elit politik dari MILF secara privat. Banyak amal usaha pendidikan yang berafiliasi kepada MILF tidak dalam bentuk yayasan yang kepemilikan saham oleh publik. Para elit politik di MILF, sesungguhnya memiliki investasi dalam beragam makna, investasi ekonomi, politik, sosial, budaya dan keagamaan. Banyak sekali amal usaha pendidikan yang memiliki jumlah siswa yang sangat banyak. Terdapat sejumlah lahan pertanian dan perkebunan yang dikelola dengan sangat baik oleh para kombatan MILF. Semuanya serba teratur dan sangat terkelola dengan sangat baik.

Bagi para pemegang dan penanggung jawab kegiatan pendidikan, sosial, dan ekonomi, kehidupan sosial yang penuh konflik tidak menghalangi para aktivis MILF untuk berhenti berinvestasi dan berkarya nyata secara kontinue. Jika kemudian terdapat perintah dari pemimpin MILF untuk melakukan persiapan menghadapi konflik, maka dengan serta mereka juga siap dengan segala situasi. Inilah yang menarik dalam sejumlah pengamatan dan focused group discussion, dengan aktivis dan elit MILF.

Pilihan Muhammadiyah untuk memperkenalkan BMT sebagai bagian dari bangunan investasi kecil di masyarakat, sesungguhnya merupakan bentuk moderasi dari pilihan berinvestasi sekaligus pilihan berkonflik, berdamai secara bersama-sama. Sebagaimana diketahui, BMT yang didesain Muhammadiyah menyediakan sejumlah produk layanan standar seperti ba'i bi'tsaman ajil, mudharabah, musyarakah, yang menggunakan 
prinsip tafakul, yakni untuk saling berbagi beban sebagaimana produk BMT di Indonesia pada umumnya (Ibrahim Warde, 2000)

BMT menjadi terobosan penting tatkala kebijakan ekonomi berbasis shariah yang dikelola oleh pemerintah Filipina tidak dapat berjalan dengan progressive yang berbasis Perbankan konvensional dan perbankan Islam seperti Al-Amana tidak banyak menjangkau lapisan masyarakat bawah di Mindanao yang relatif tidak memiliki sejumlah barang untuk diagunkan tatkala melakukan hendak melakukan pinjaman. BMT pola bottom up justru memiliki potensi yang lus membangun perekonomian dan investasi ekonomi berbasis shariah dapat berjalan dengan produktif. Sejumlah studi tentang konflik memberikan penjelasan yang unik, bahwa masyarakat yang mengalami konflik identitas, cenderung memiliki solidaritas untuk menyelesaikan masalah bersamasama. Sangat berbeda dengan konflik sosial yang terjadi sebagai akibat dari konflik non identitas seperti konflik ekonomi, konflik politik, maupun konflik vertikal lainnya (Surwandono, 2013, Timothy Donais, 2005).

Prinsip ekonomi shariah yang berbasiskan nilai kebersamaan, akan memungkinkan kepada setiap fihak yang berhubungan dalam proses investasi akan saling bertanggung jawab. Pemilik modal yang menginvestasikan dalam lembaga ekonomi shariah juga akan sedemikian rupa menjaga agar distribusi modal yang diberikan akan dapat berputar dengan cara yang efektif. Perbankan atau BMT yang mendapatkan amanah untuk mendistribusikan modal tersebut kepada para pengguna juga akan mencari pengguna yang benar-benar bertanggung jawab dalam mengelola modal yang diperoleh dari perbankan shariah.

Lantas apa kaitannya dengan pilihan konflik dan perdamaian? Secara hipotetik, ketidakpastian investasi di daerah konflik lebih disebabkan dinamisnya konflik, sehingga perputaran roda ekonomi dan investasi dapat terhambat. Pada sisi yang lain, dinamisnya konflik, lebih disebabkan oleh pilihan politik dari para elit politik untuk memperjuangkan kepentingan politik dan ekonomi. Jika para pemilik modal yang sekaligus pemangku konflik tersebut menghendaki agar modal yang diinvestasikan tersebut dapat berkembang secara produktif, maka para pemilik modal dan semuanya saja yang terlibat dalam konflik harus berusaha sedemikian rupa agar situasi dalam masyarakat adalah stabil. Dari sinilah sesungguhnya inisiatif pembangunan sistem ekonomi shariah yang berbentuk BMT menjadi sangat realistis untuk mendorong arus perdamaian di Mindanao.

Para elit politik MILF, yang notabene sebagai kelompok yang memiliki kuasa ekonomi, harus mendayagunakan potensi ekonomi yang ada untuk menggerakan ekonomi berbasis shariah di Mindanao. Bergeraknya ekonomi shariah untuk membangun bidang sosial, pendidikan, kesehatan, maupun infrastruktur dan supra-struktur di Mindanao akan mengubah arah pilihan konflik dalam level intermediate dan warakan semakin berkurang. Pilihan konflik dari elit di muslim Mindanao lebih mengartikulasikan konflik politik dalam dimensi debat pemikiran, kritik kebijakan, pemberdayaan masyarakat, karena dengan pilihan konflik di area inilah sesungguhnya investasi sosial, ekonomi, politik dan budaya di Mindanao dapat berjalan secara efektif.

\section{KESIMPULAN}

Dari diskusi di atas, terdapat pandangan penting bahwa proses pembangunan perdamaian dapat diawali dengan mengajak fihak-fihak yang berkonflik untuk membangun investasi ekonomi yang berkeadilan social, progressive dan tepat guna. Salah satu model pelembagaan ekonomi di tingkat grass root adalah micro-finance. Pertumbuhan investasi ekonomi yang baik melalui micro-finance dan ditambah dengan dukungan macro finance yang kuat, akan memberikan effek multiplier terhadap stakeholder konflik untuk dapat merumuskan kebijakan konflik yang bersifat moderat. Yang pada akhirnya, moderasi pilihan dalam berkonflik akan menjadi jalan lapang bagi bertahannya perdamaian di daerah konflik.

\section{BIBLIOGRAFI}

Abdelkarim, Kamal Hassan and Hassan Ahmed Yusuf, 2010, " Investment Risk in Islamic Finance ", dalam Islamic Finance: Instruments 
And Markets, London, Blomsbury, 2010

Alam, Masudul Choudhury, 2007, The Universal Paradigm and The Islami World-System: Economy, Society, Ethics and Science, London, World Scientific, 2007

Askandar, Kamarulzaman, Ayesah Abu Bakar (ed.), 2005, The Mindanao Conflict, Penang, SEACSN Publications

Asutay, Mehmet, 2010, "Islamic Microfinance: Fulfilling Social and Developmental Expectations", dalam Islamic Finance: Instruments And Markets, London, Blomsbury, 2010

Buendia, Rizal, 2008, "Looking into the Future of Moro Self-Determination in the Philippines", Philippine Political Science Journal 29

Carolina G. Hernandez, 2002, "Contextualizing Armed Conflicts in Southeast Asian Region", dalam Ed Garcia (ddk), Waging Peace in The Philippines: Looking Back and Moving Forward, Conference Proceeding 10-12 Desember

Cesar, Adib Majul, Muslims in the Philippines, Diliman, UPI Press, 1999

Donais, Timothy, 2005, The Political Economy Of Peacebuilding In Post-Dayton Bosnia, London, Routledge

Framework Agreement on the Formation of the International Contact Group for the GRP-MILF Peace Process (September 15, 2009).

Ibrahim Warde, 2000, Islamic Finance in the Global Economy, Edinburgh, Edinburgh University Press

Ibrahim, Sami Al-Suwailem, 2002, "Decision-making under uncertainty: An Islamic perspective" dalam Munawar lqbal, David T. Llewellyn (eds.), Islamic Banking and Finance New Perspectives on ProfitSharing and Risk, Northhampton, Edward Elgar

Latif, Qudeer And Susia Crawford, "Introduction To Islamic Financial Risk Management Products", Islamic Finance: Instruments And Markets, London, Blomsbury, 2010

Rasul, Amina, 2005, Contending Viewpoints Viewpoints: Analyzing The 1996 Mnlf-Grp Final Peace Agreement, PCID Lead Convenor.

Rasul, Amina,2007, “Contending Viewpoints Viewpoints: Analyzing The 1996 MNLF-GRP Final Peace Agreement", Manila

Rood, Steven.,2005, Forging Sustainable Peace in Mindanao: The Role of Civil Society, Policy Studies No. 17. Washington D.C.: East-West Center

Santos, Jr., Soliman M, 2005, “Peace negotiations Between the Philippine Government and the Moro Islamic Liberation Front: Causes and Prescriptions." Working Papers No. 3. East-West Center Washington

Santos, Jr. Solimon, 2005, Charter Change And The Peace Process: Some Key Propositions, Institute For Autonomy And Governance,.Konrad Adenauer-Stiftung, No. 4 September 12

Surwandono, 2013, Manajemen Konflik Separatisme: Dinamika Negosiasi Dalam Penyelesaian Konflik Mindanao, Yogyakarta, Pustaka Pelajar

Tabang Mindanaw, 2005, "People Making Peace" A Video Documentation on Intergrated Return and Rehabilitation Program. Philippines: Tabang Mindanao IRRP and Philippines-Canada Development Fund

The Philippines, (2009): Opinion Survey And In-Depth Research, Geneva, ICRC

Venardos, Angelo M. 2005, Islamic Banking \& Finance In Southeast Asia:Its Development \& Future, Singapore, World Scientific Publishing

www.c-r.org/sites/c-r.org/files/2009\%20

Agmt\%20ICG\%20formation.pdf [accessed July 2013] www.bsp.gov.ph/publications/speeches.asp? $i d=456$ akses 20 Januari 2015)

www.mb.com.ph/7-8-gdp-growth-in-mindanao-for-2015-seen/ www.hdcentre.org/projects/philippines-mindanao www.c-r.org/our-work/philippines www.asiafoundation.org/country/ overview/philippines wnw.muhammadiyah.or.id/ 